Ann. Biol. anim. Bioch. Biophys., 1977, 17 (3 B), 483-498.

\title{
Prolactin secretion in infertile men before and after treatment with bromocriptine
}

\author{
par D. BOUCHER, J. HERMABESSIERE, M. DOLY \\ with the technical assistance of D. CHEYVIALLE, J. SOUBRIER
}

Laboratoire de Physiologie, Faculté de Médecine, 63001 Clermont-Ferrand

Laboratoire des Isotopes, Centre Jean-Perrin, 63001 Clermont-Ferrand, France

Summary. This report studies prolactin secretion in infertile men and the effect of bromocriptine treatment.

Twelve normal and 90 infertile men are studied. Prolactin, LH, FSH and testosterone are specifically radioimmunoassayed, and urinary androgens determined by gas chromatography. Spermatogenesis is determined using spermocytograms or by testis biopsy; LH. $\mathrm{RH}$ and TRH tests are used. In the second part of the study, 18 infertile men having high prolactin levels are treated with bromocriptine for one month $(5 \mathrm{mg} / \mathrm{day})$, and the above tests repeated during the treatment.

Using spermograms and the $\mathrm{LH}-\mathrm{RH}$ test, the patients are divided into the following groups : control (1), normogonadotropics (2), hypogonadotropics with lower titers of LH and/or FSH (3), hypergonadotropics with LH (and sometimes FSH) response to LH-RH greater than normal with normal or slightly higher basic levels (4), azoopermia with no spermatogenesis (5).

Prolactin secretion and correlation with gonadotropins and androgens. Prolactin secretion is higher before or after TRH in $40 \mathrm{p} .100$ of infertile men. There seems to be a correlation between gonadotropins and prolactin ; this result provides additional evidence that there is no antagonism between prolactin and gonadotropin secretion in man. Prolactin secretion is frequently correlated with plasma testosterone or urinary androgens. However, this correlation is negative when spermatogenesis is blocked before the spermatocyte stage.

Results obtained during treatment with bromocriptine. Prolactin secretion, basal levels al,d response to TRH are reduced. At the same time, basic FSH and LH increase and androgens decrease, but these modifications are slight and the range of individual variation is wide. The number of spermatozoa also increases considerably $\left(15\right.$ to $\left.31 \times 10^{6} / \mathrm{ml}\right)$. This result suggests that hyperprolactinemia interfers with the final stages of spermatogenesis and that bromocriptine treatment leads to resumption of normal gonadic function.

\section{Introduction.}

Prolactin has been isolated in man and defined as an antepituitary hormone, different from the growth hormone (Guyda, Hwang and Friesen, 1971 ; Lewis et al., 
1971). Specific radioimmunological determination (Hwang ef al., 1971) enabled us to undertake the physiopathological study of prolactin secretion.

It rapidly became evident that, due to a plasmatic half-life of about $15 \mathrm{~min}$, a circadian rhythm (Nokin et al., 1972) and the effect of stress (sometimes considerable) (Noel et al., 1972), the interpretation of an isolated prolactinemia value was hazardous. It was thus necessary to carry out dynamic tests to estimate the stimulation or inhibition of secretion ; these tests used either TRH (thyrotropin-releasing hormone), known to release prolactin (Bowers ef al., 1973 ; Jacobs ef al., 1971), or rye ergot derivatives such as bromocriptine which inhibits prolactin secretion (Besser ef al., 1972 ; Del Pozo ef al., 1972).

The relationships between prolactin secretion and the male gonadic function are not yet well known, especially in man ; however, some studies suggest that prolactin has a stimulatory effect. According to these, prolactin would increase the testosterone secretion (Rubin ef al., 1975), and an induced hyperprolactinemia would be accompanied by testosterone response, greater after stimulation by HCG (Ambrosi ef al., 1976).

On the other hand, contrasting results favor an inhibitory effect. The majority of hyperprolactinemic patients are hypogonadic or impotent (Boyar et al., 1974 ; Thorner ef al., 1974 ; Fossati, Strauch and Tourniaire, 1976) ; induced hyperprolactinemia is followed by lower DHT response after stimulation by HCG (Magrini ef al., 1976) and induced hypoprolactinemia is accompanied by increased testosterone secretion after HCG (Besser and Thorner, 1975).

Given these apparently contradictory results, the aim of this report is to study prolactin secretion in normal and infertile men, and to determine the consequences of curbing prolactin secretion with bromocriptine.

\section{Material and methods.}

\section{Patients.}

One hundred and two men (12 controls and 90 sterile subjects), between 20 and 38 years of age, were thoroughly examined. The 90 sterile patients were married and had been for at least three years ; the normal functioning of the hypothalamo-pituitaryovarian activity of their wives had been checked. The patients did not present any hepatic or renal malfunction nor any visible signs of pituitary tumor. After clinical examination, they underwent biological evaluation, including one or two spermocytograms, a spermoculture to look for possible genital infection, a thermograph of the scrotum to discover eventual varicocele, a karyotype, static and dynamic hormonal studies of urine and plasma represented by $\mathrm{LH}-\mathrm{RH}$ and TRH tests, and a bilateral testis biopsy for the cases of azoospermia or severe oligospermia.

\section{Classification for study of prolactin secretion (table 1).}

The 102 patients examined were selected from a larger group of infertile patients, a defailed study of which is published elsewhere (Boucher et al., 1977).

Controls : Twelve men, 20 to 35 years old, with at least one child, and presenting no known or discernible disease. 
PRL in infertile men

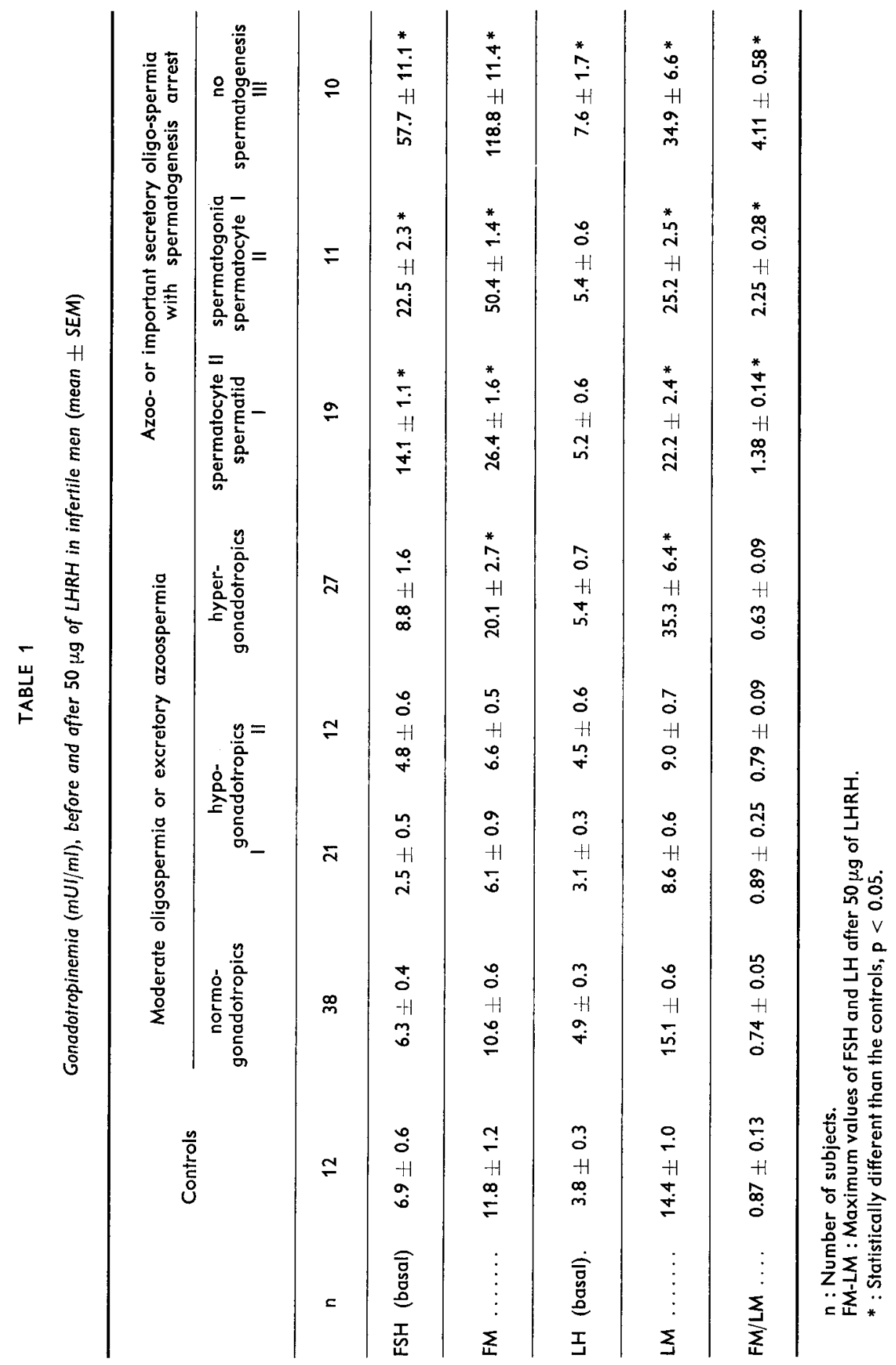


Cases of oligospermia or excretory azoospermia : These patients did not present large blockage of spermatogenesis. This group includes excretory azoospermia, oligozoospermia ( 2 to $40 \times 10^{6}$ spermatozoa $/ \mathrm{ml}$ ), asthenospermia (motility lower than $70 \mathrm{p}$. 100 1 hour after emission), teratospermia (number of abnormal forms higher than 40 p. 100) and cases of idiopathic sterility. They were divided into four sub-groups, according to the character of $\mathrm{LH}$ and FSH secretion before and after LH-RH :

Normogonadotropics : normal FSH and LH secretion,

Hypogonadotropics I : low basal LH or FSH levels,

Hypogonadotropics II : normal basal level, low response to LH-RH,

Hypergonadotropics : normal or sligthly high levels, exaggerated response to $\mathrm{LH}$ and sometimes to FSH.

Cases of severe secretory azoo- or oligospermia : These patients presented spermatogenetic blockage ; they constitute three groups according to degree of blockage :

Azoospermia I : blockage at spermatocyte II or spermatid stage,

Azoospermia II : blockage at spermatogonia or spermatocyte I stage,

Azoospermia III : Sertoli cells only, Klinefelter syndrome (XXY), bilateral cryptochidia.

\section{Bromocriptine treatment (CB 154 from Sandoz Laboratories).}

Eighteen oligospermic infertile subjects with exaggerated prolactin secretion (basal level $\mathrm{PO}>300 \mu \mathrm{U} / \mathrm{ml})$ in response to stimulation by $\mathrm{TRH}(\Delta \mathrm{P}>800 \mu \mathrm{U} / \mathrm{ml})$ were treated with bromocriptine for a period of 30 days at a dose of $5 \mathrm{mg} /$ day $(1$ tablet morning and evening). Between day 25 and day 30 of treatment, they were completely examined : spermocylogram, urinary and plasma hormones, LH-RH and TRH tests. This preliminary examination after the beginning of the treatment was designed to reveal any possible spermiogenetic activity, and mainly to interrupt the treatment which could prove harmful.

\section{Analytical methods.}

a) The spermatograms included determination of spermatozoon number and motility and spermatozoon morphology, using the classification proposed by David et al., 1975).

b) Hormonal examination of urine was carried out on the urine collected over 24 hours. The 17 hydroxysteroids and the 17 celosteroids were assayed by the colorimetric method. Androsterone, etiocholanolone and dihydroepiandrosterone were assayed by gas chromatography on a Packard 7400 chromatograph : flame ionization detector at $290^{\circ} \mathrm{C}$, injection chamber at $280^{\circ} \mathrm{C}$, a glass column containing an OV1 1 p. 100 phase, temperature programmed at $1 \mathrm{o} \mathrm{C} / \mathrm{min}$ from 210 to $270^{\circ} \mathrm{C}$, internal epicoprostanol standard. Urinary FSH and LH were assayed by immunochemical method with luteonosticon and FSH-nosticon reactives from the Organon Laboratories.

c) Plasma assay of testerone, FSH, LH and prolactin was carried out by radioimmunological methods. Blood samples were taken in the morning between 8: 30 and $9: 00$. 
Testosterone assay was done after adsorption on coal-dextran and the results expressed in $\mathrm{ng} / \mathrm{ml}$.

The method used for the FSH was that of « double antibody » with the second antibody fixed on activated cellulose. The standard was a MRC 68/39 preparation (immunological equivalent : 2,830 IU per $\mathrm{mg}$; biological activity : 3,500 IU per $\mathrm{mg}$ ). The results are expressed in $\mathrm{mlU} / \mathrm{ml}, 1 \mathrm{mlU}=0.353 \mathrm{ng}$.

The method for $\mathrm{LH}$ was identical to that used for FSH. The MRC $68 / 40$ preparation constituted the standard, its immunological equivalent being 2,160 IU per $\mathrm{mg}$ of $\mathrm{LH}$, and its biological activity 2,000 IU IRP2 per $1 \mathrm{mg}$. The results are expressed in $\mathrm{mIU} / \mathrm{ml}$, $1 \mathrm{mIU}=0.463 \mathrm{ng}$.

The reference standard for prolactin was a MRC 71/222; the immunological equivalent is $40 \mathrm{IU}$ per $1 \mathrm{mg}$ of prolactin supplied by the NIH $(\mathrm{NIH}-\mathrm{V}-\mathrm{L}-\mathrm{S}=1)$. The results are expressed in $\mu \mathrm{U} / \mathrm{ml}, 1 \mu \mathrm{U}=0.025 \mathrm{ng}$.

d) The dynamic examination included a LH-RH test and a TRH test carried out simultaneously, according to the modalities described in detail elsewhere (Boucher, 1976). The tests were done between $8: 30$ and $12: 30$ p.m. on an empty stomach. An intravenous catheter was placed $20 \mathrm{~min}$ before the beginning of the test. $50 \mu \mathrm{g}$ synthetic LH-RH (Stimu-LH, Roussel) and $200 \mu \mathrm{g}$ TRH (Laboratories Roche) were quickly injected intravenously at 0 hour. The blood samples were immediately centrifuged and the plasma stored at $-20^{\circ} \mathrm{C}$. FSH and $\mathrm{LH}$ were assayed at $0,10,20,30,45$, $60,90,120$ and $150 \mathrm{~min}$; prolactin was assayed at 0,30,60 and $120 \mathrm{~min}$. The results were analyzed, taking into particular consideration basal values (PO, LHO, FSHO) the highest levels after TRH or LH-RH stimulation (P30, LHM, FSHM), and the cumulative responses equal to the surfaces defined by the response curve and the straight line continuous to the basal level (SPRL, SLH, SFSH).

\section{Statistical analysis.}

The statistical study was done on a programmable Monroe calculator. Various data were compared using analysis of the variant. For some parameters, different correlations were studied statistically, i.e. determination of the correlation coefficient between two parameters (Snedecor and Cochran, 1967).

\section{Results.}

Prolactin secretion before and after TRH (table 2).

Twenty min after the intravenous catheter was placed, basal prolactin level was $226 \pm 20 \mu \mathrm{U} / \mathrm{ml}$ in the controls. In the different groups of infertile subjects this basal value was higher, but the differences were non-significant, with the exception of the subjects presenting an arrest of spermatogenesis at spermatocycle II or spermatid stage.

Under our experimental conditions, and in all groups considered, the prolactin surge took place $30 \mathrm{~min}$ after intravenous injection of TRH. At $60 \mathrm{~min}$, prolactinemia diminished, but still remained significantly higher than the basal level. However, 
D. BOUCHER ef al.

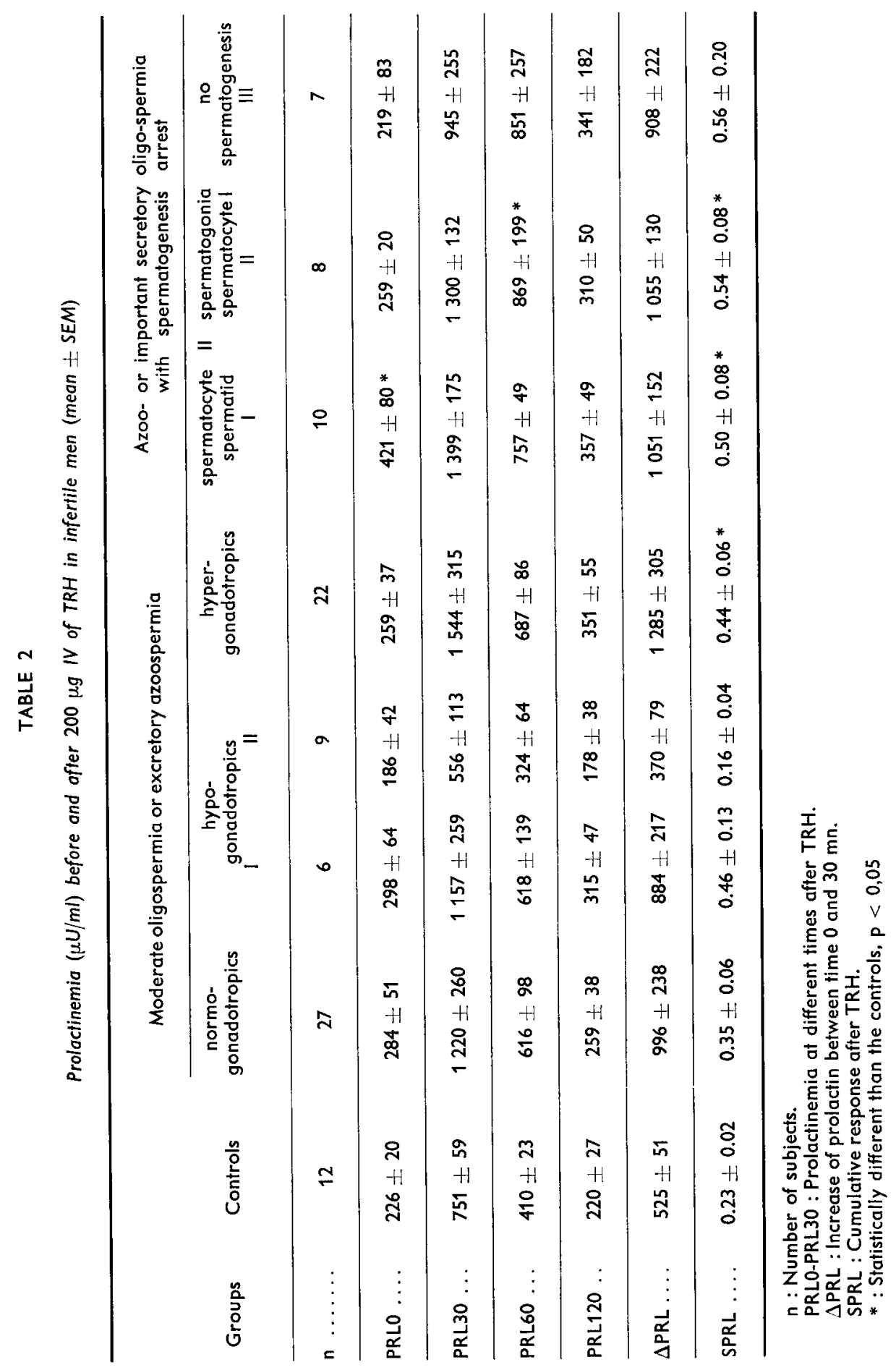


120 min after injection, the prolactin levels were not significantly different from the basal level.

We noted a significant correlation between the basal level (PO) and the surge after TRH (P30) in all of the infertile subjects $(r=0.598, p<0.001)$ and also in the group of oligospermic-normogonadotropic subjects $(r=0.818, p<0.001)$. In the same groups there is a significant relation between $\mathrm{PO}$ and the other criteria for estimating TRHinduced prolactin release $(\triangle P, S P)$. On the other hand, these correlations are not significant for the other groups when they are studied separately.

Generally, the relations between criteria used for estimating TRH prolactin release are significant, in particular $\mathrm{P} 30-\Delta \mathrm{P}$ and SP. Only the percentage increase as compared to the basal level $(\triangle P / P O)$ was not correlated with the other parameters.

When compared to the controls, oligospermic hypogonadotropic (II) subjects presented lower but not statistically significant prolactin release after TRH. In all the other groups of infertile subjects, we noted an increase of prolactin surge, significant in the groups of oligospermic hypergonadotropics and also in the group of secretory azoospermic patients considered as a whole or taking into account the different degrees of spermatogenetic blockage. No differences were noted between the three groups of azoospermic patients.

The subjects in each group did not all present abnormal prolactin secretion. Before or after TRH, the criteria used ( $\mathrm{PO}>300 \mu \mathrm{U} / \mathrm{ml}$ or $\Delta \mathrm{P}>800 \mu \mathrm{U} / \mathrm{ml}$ ) showed high prolactinemia in $50 \mathrm{p} .100$ of the azoospermic or oligospermic hypergonadotropic subjects, in 25 p. 100 of the oligospermic normogonadotropic subjects and in 10 p. 100 of the oligospermic hypogonadotropics.

When the infertile patients were separated into three groups ( $\mathrm{PO}<80 \mu \mathrm{U} / \mathrm{ml}$; $\mathrm{PO}>300 \mu \mathrm{U} / \mathrm{ml} ; 80<\mathrm{PO}<300 \mu \mathrm{U} / \mathrm{ml})$, FSH, LH and urinary androgens A + E (androsterone + etiocholanolone) were significantly higher before and after LH-RH in the groups where basal prolactinemia was greater than $300 \mu \mathrm{U} / \mathrm{ml}$.

However, there seems to be no hypoprolactinemia in man. In fact, there is no difference in the parameters studied between groups $\mathrm{PO}<80 \mu \mathrm{U} / \mathrm{ml}$ and $80<\mathrm{PO}$ $<300 \mu \mathrm{U} / \mathrm{ml}$.

\section{Correlations between prolactin and other hormones.}

We systematically looked for correlation, within the various groups, between prolactin and other hormone secretions such as plasma testosterone, urinary androgens $A+E$ and plasma FSH and LH.

Prolactin-androgens. In infertile subjects, there was a significant correlation between blood testosterone and urinary androgens. In the total number of infertile patients, we noted, on the one hand, a significant relation between basal prolactin and testosterone, and on the other, between basal prolactin and urinary androgens $(A+E)$. When each group was considered separately, we frequently found the same correlations, particularly between prolactin and $A+E$. This correlation disappears in the oligospermia hypergonadotropic subjects, but becomes negative $(P=0.05)$ in the cases of very early blockage of spermatogeriesis.

Prolactin-FSH. We have never observed any correlation between basal FSH and prolactin values. We did note, however, a significant relation between FSH response 
after LH-RH and prolactin response after TRH in control subjects (SF-P30, $r=0.817$ ) oligospermic normogonadotropics (SF-P30, $r=0.408$ ) and hypogonadotropics (SF-SP, $r=0.953$ ). A significant negative correlation appeared between basal prolactin levels and FSH surge after LH-RH in azoospermics (PO-SF, $r=0.536$ ) and oligospermic hypergonadotropics (PO-FM, $r=0.505$ ).

Prolactin- $\mathrm{LH}$. There was no evidence of a close relation between basal prolactin and LH secretions, although we had noted a hardly significant correlation $(P=0.05)$ in oligospermic hypergonadotropics (PO-LO, $r=0.478$ ). We observed a significant correlation between prolactin and $\mathrm{LH}$ surge after TRH and $\mathrm{LH}-\mathrm{RH}$, respectively, in controls (P30-SL, $r=0.712$ ) and azoospermics (SP-SL, $r=0.460$ ).

Prolactin-FSH/LH. In cases of spermatogenetic arrest at spermatocyte I stage, the surge of PRL after TRH corresponds significantly to the basal level of $\mathrm{FSH} / \mathrm{LH}$ before (FO/LO, $r=0.842)$ and after (FM/LM, $r=0.828) \mathrm{LH}-\mathrm{RH}$ stimulation. There also appears to be a hardly significant relation in oligospermic hypohypergonadotropics.

Bromocriptine treatment (table 3).

Eighteen infertile men presenting high prolactin levels before or after TRH were treated for one month with bromocriptine $(5 \mathrm{mg} /$ day). Examination between the days 25 and 30 of treatment gave the following results :

\section{Effect on prolactin secretion (fig. 1).}

Treatment was followed by a definite decrease in prolactin secretion which became inferior to the controls before and after TRH stimulation. However, in 4 cases out of 18 , inhibition seemed to be slight, basal values remained between 210 and $330 \mu \mathrm{U} / \mathrm{ml}$, and in 2 of these cases, increase after TRH was higher than $800 \mu \mathrm{U} / \mathrm{ml}$.

\section{Effect on other hormonal secretions (table 3).}

Hormonal secretions varied from one subject to another. The average showed an increase of basal FSH and $\mathrm{LH}$ values, but the variations were non-significant. Urinary FSH was slightly lower, whereas urinary $\mathrm{LH}$ increased $(P=0.05)$. The surge of $\mathrm{LH}$ and $\mathrm{FSH}$ after $\mathrm{LH}-\mathrm{RH}$ stimulation was unchanged. Plasma testosterone and urinary androgens $(A+E)$ were lower, but only urinary androgen decrease was significant $(P=0.05)$, this decrease being essentially related to the etiocholanolone.

A separate study of the two patient groups (PO $>300 \mu \mathrm{U} / \mathrm{ml}$ on the one hand, $\mathrm{PO}<300 \mu \mathrm{U} / \mathrm{ml}$ and $\Delta \mathrm{P}>800 \mu \mathrm{U} / \mathrm{ml}$ on the other) showed comparable results. The absence of a significant difference seemed to be due to the small number of patients (9) in each group.

\section{Spermogram study.}

In the whole group (18 subjects) the treatment caused large changes in the number of spermatozoa per $\mathrm{ml}$; this significantly increased from $15.5 \pm 2.8 \times 10^{6}$ before treatment (extreme values 0.35 to $45.0 \times 10^{6}$ ) to $31.6 \pm 6.1 \times 10^{6}$ after treatment (extreme values 0.35 to $105.0 \times 10^{6}$ ). On the other hand, motility one hour after emission, the number of normal forms and the volume of ejaculation were not statistically 
modified. Thus, 11 subjects showed definite improvement, 3 remained unchanged, 2 presented more spermatozoa per $\mathrm{ml}$ but a considerable decrease in motility, and 2 showed a decrease in the number and the motility of spermatozoa.

\section{TABLE 3}

Evolution of hormonal secretion and spermograms before and after treatment with bromocriptine in infertile men (mean \pm SEM)

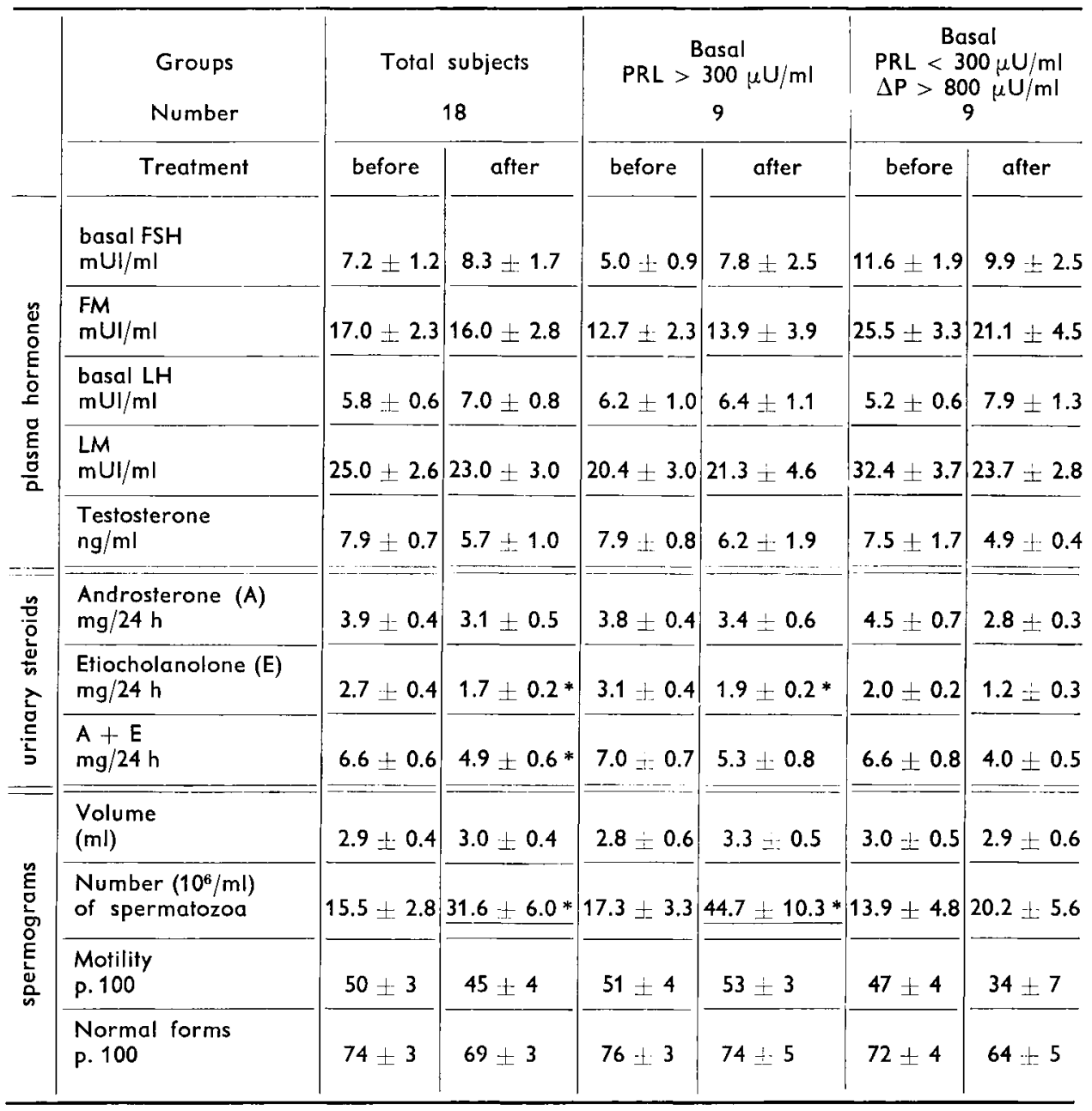

* : Statistically different than the corresponding value before treatment, $p<0,05$.

$\Delta P$ : Increase of prolactinemia after $200 \mu \mathrm{g} I V$ of TRH.

FM, LM : Peak of FSH and LH after $50 \mu \mathrm{g}$ IV of LHRH.

In the 9 subjects who presented basal prolactinemia higher than $300 \mu \mathrm{U} / \mathrm{ml}$ before treatment, we noted a significant increase in the number of spermatozoa per $\mathrm{ml}$, i.e. $17.0 \pm 3.3 \times 10^{6}$ before treatment to $44.7 \pm 10.3 \times 10^{6}$ after treatment (extreme 


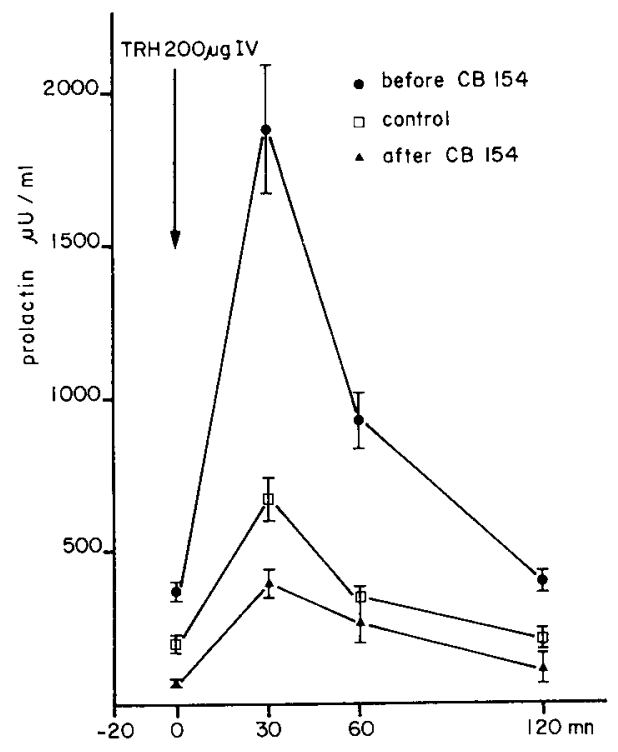

FIG. 1. - Prolactin secretion (basal level and response ofter TRH) before and after treatment with bromocriptine in infertile men (mean \pm SEM).

value were from 0.4 to $36.0 \times 10^{6} / \mathrm{ml}$ and from 1.4 to $105.0 \times 10^{6} / \mathrm{ml}$, respectively). Eight subjects showed definite improvement, the increase being higher than 60 p. 100 for each individual. In one case, the number of spermatozoa was only slightly modified.

In the 9 subjects who presented basal prolactinemia lower than $300 \mu \mathrm{U} / \mathrm{ml}$ before treatment and increased prolactineamia higher than $800 \mu \mathrm{U} / \mathrm{ml}$ after TRH $(\Delta P)$, we noted in 3 cases a definite increase in the number of spermatozoa, in 2 cases no change, in 2 cases more spermatozoa per $\mathrm{ml}$ but a noticeable decrease in motility, and in 2 cases a considerable decrease in both number and motility. A statistical study of the spermograms of the whole group did not reveal any significant variations.

\section{Discussion.}

The functioning and degree of malfunction of the hypothalamopituitary-gonadic axis in infertile men can be defined using the LH-RH test (Franchimont et al., 1973 ; Boucher ef al., 1976). Basal FSH level and cumulative responses after LH-RH increased when spermatogenesis was blocked, whereas $\mathrm{LH}$ secretion was normal or increased slightly. This result would suggest the germinal cell secretion of an « inhibin » and its preferential intervention in FSH feedback (Setchell, 1974 ; Franchimont et al., 1975).

Prolactin and gonadotropins.

The prolactin level we observed before or after TRH in a normal healthy man corresponds to that noted by other authors (L'Hermite et al., 1975 ; Franchimont ef al., 
1976). Among the sterile men, about 40 p. 100 presented increased prolactin secretion before or after TRH ; this was most frequent in the case of exaggerated LH and/or FSH responses after $\mathrm{LH}-\mathrm{RH}$ stimulation; it was also seen in about 30 p. 100 of the infertile normogonadotropics. In most of the groups, there is a correlation between prolactin and gonadotropin which agrees with the results noted after TRH by Mortimer et al. (1973a) and the observations on patients presenting hyperprolactinemia and hypogonadism (Mortimer et al., 1973b). It therefore seems that in man the secretion of the hormones $\mathrm{FSH}, \mathrm{LH}$ and prolactin generally evolves in the same way, and not inversely, as some observations on animals would lead us to believe (Ben-David, Danon and Sulman, 1971). Hyperprolactinemia is frequently related to LH deficiency in humans (Boyar et al., 1974) and this must be associated to hypothalamo-pituitary tumoral processes.

\section{Prolactin and gonadic function.}

The role of prolactin on the gonadic function is still not well known, although much discussed.

a) Some studies fovour a stimulating effect of prolactin on $\mathrm{LH}$ and androgens. In vitro prolactin potentializes $\mathrm{LH}$ action on testis synthesis and secretion of testosterone (Hafiez, Bartke and Lloyd, 1972) ; it stimulates the prostate gland in man (Farnsworth, 1972) as well as in rat (Kledzik et al., 1976) ; it activates prostate gland protein and RNA synthesis, but does not modify the testosterone melabolism at that level (Johansson, 1975, 1976).

Prolactin associate with $\mathrm{LH}$ in vivo restores normal testosteronemia in hypophysectomized rat (Hafiez, Llyod and Bartke, 1972), and intervenes in testis and accessory organ development (Negro-Vilar, Krulich and MacCann, 1973). In the male hamster exposed to short day length, prolactin significantly increases the weight of testis, seminal vesicles and prostate gland, as well as increasing plasma testosterone level (Bartke, Croft and Dalterio, 1975). Testosterone peaks in man are preceded by peaks of LH and prolactin $60 \mathrm{~min}$ beforehand (Rubin, Poland and Tower, 1976), and an increase in prolactin is followed by an increase in testosterone (Rubin et al., 1975). For Ambrosi et al. (1976), hyperprolactinemia induced by sulpiride is accompanied by increased response to testosterone after HCG stimulation.

b) On the other hand, some data indicate prolactin inhibitory activity. Experimental hyperprolactinemia in women is accompanied by a shorter luteal phase during which LH, FSH and progesterone values are significantly lower (Delvoye ef al., 1974). TRH treatment producing hyperprolactinemia is followed by suppression of the preovulatory LH surge (Bohnet, Dahlen and Schneider, 1974). Hyperprolactinemia in women is very often accompanied by amenorrhea, and in men by impotence or hypogonadism (Thorner et al., 1974 ; Fossati, Strauch and Tourniaire, 1976) ; androgen secretion consecutive to HCG treatment is greater when prolactin is inhibited (Besser and Thorner, 1975).

In rat, experimental hyperprolactinemia, consecutive to transplant of a prolactin pituitary tumor, is followed by a lower testosterone level, genital atrophy and spermiogenetic arrest (Fang, Refetoff and Rosenfield, 1974). The high prolactin levels may 
contribute to long-term inhibition of the estrous cycle in female rat (Kerdelhué ef al., 1976).

Our results would suggest double prolactin action; the correlations between prolactin and plasma or urine androgens seem to indicate that prolactin, alone or in association with gonadotropins, stimulates the secretion and metabolism of androgens. On the other hand, negative prolactin-testosterone correlation in the cases of very early spermatogenetic arrest would suggest inhibitory action. We think the prolactin effect in man depends on the secretion level of that hormone and on gonadotropin balance, i.e. prolactin appears to stimulate the androgenic function in nearly normal conditions, but on the contrary, to inhibit it when there is hypersecretion of prolactin and $\mathrm{FSH}$ or $\mathrm{LH}$.

\section{Bromocriptine treatment.}

Most of the studies using bromocriptine have been carried out on women, in particular during the amenorrhea-galactorrhea syndrome. This rye ergot alkaloid inhibits the secretion of prolactin (Del Pozo ef al., 1972), and its use in cases of hyperprolactinemia provokes the reappearance of the menstrual cycle in most cases (Besser ef al., 1972 ; Del Pozo ef al., 1974 ; Seki, Seki and Okumura, 1975 ; Fossati, Strauch and Tourniaire, 1976). Bromocriptine does not modify LH or FSH, but increases estradiol secretion (Seppala et al., 1976). For Del Pozo ef al. (1974) bromocriptine treatment is usually accompanied by an increase of $\mathrm{LH}$ and $\mathrm{FSH}$.

The treatment of men with bromocriptine seems to have a variable action on $\mathrm{LH}$, FSH and androgens. On an average, it appears to increase FSH and $\mathrm{LH}$, and decrease testosterone and urinary androgens. The most interesting data show a large increase in the number of spermatozoa that appears after hyperprolactinemia has been inhibited for one month. These results concord with those of other authors studying the improvement of fertility in men (Besser and Thorner, 1975); they are in contradiction with the data on prolactin-spermatogenetic relationships in animals such as the studies of Woods and Simpson (1961) on hypophysectomized rat, Bartke (1971) on hypophysectomized mouse and Bartke and Llyod (1970) on dwarf mouse which have effectively demonstrated the synergic action of prolactin and of $\mathrm{LH}$ in maintaining or restoring spermatogenesis. This action seems to be secondary to increased biosynthesis and testosterone secretion (Hafiez, Lloyd and Bartke, 1972).

Therefore, hyperprolactinemia in man would seem to slow down spermatogenesis; in animals, the absence of prolactin is prejudicial to spermatogenesis, but prolonged hyperprolactinemia may cause blockage of spermatogenesis (Fang, Refetoff and Rosenfield, 1974). Thus, there may be double prolactin action, favorable with normal or low levels, and unfavorable with high levels.

Knowing that, as in other mammals, the length of the various spermatogenetic stages in man is independent of endocrine conditions (Heller and Clermont 1963, 1964), the impact of hyperprolactinemia may thus be determined. We observe improvement 25 to 30 days after the beginning of the treatment. Since 24 hours are required to transform spermatocytes II into spermatids, spermiogenesis (spermatids-spermatozoa) lasts about 23 days, and it takes at least one day for spermatozoa to pass into the epididymis (Heller, Teshima and Rowley, 1969) the inhibitory effect of hyperprolactinemia 
is probably situated at the spermatocyte 11 or the spermatid stage, or at the time of epididymal transit.

\section{Conclusion.}

In most cases, the degree of hypothalamo-pituitary-gonadic axis malfunction may be determined by the $\mathrm{LH}-\mathrm{RH}$ test. $\mathrm{FSH}$, in particular, increases progressively as spermatogenetic blockage occurs at earlier stages, thus confirming germinal cell secretion of an inhibin exerting negative feedback on FSH secretion.

In the absence of any discernible tumoral process, the study of prolactin secretion shows that 40 p. 100 of sterile men present a high level of prolactinemia before or after stimulation by TRH. Prolactin, FSH and LH usually evolve in the same way; it would therefore seem that there is no antagonism between prolactin and gonadotropin secretion in man. The correlation between prolactin and androgens indicates prolactin stimulation of the secretion and the metabolism of androgens. However, since this correlation disappears in some groups, and may even become negative, an inhibition may appear, particularly in cases of hyperprolactinemia. This may be due to gonadotropin inhibition of peripheral receptors.

Prolactin secretion greatly diminishes when men presenting a high level are treated with bromocriptine. Changes in $\mathrm{LH}, \mathrm{FSH}$ and androgens vary from one subject to another; the average result is increased FSH and LH while androgens decrease. The large augmentation in the number of spermatozoa per $\mathrm{ml}$ after a one-month treatment would suggest that hyperprolactinemia inhibits the final stages of spermatogenesis (spermatocytes II or spermatids) and/or epididymal transit. Bromocriptine may represent an efficient therapy for masculine infertility in cases where hyperprolactinemia is present. Further studies are necessary in order to confirm these first results, and to determine the consequences of this treatment on a long-term basis.

8 Colloque de Neuroendocrinologie. - Table ronde Prolactine.

Tours, 7 septembre 1976.

Acknowledgments. - We thank Mr. J. Grizard (INRA, Theix) who planned the program for study of the correlations.

Résumé. L'objet du présent travail est d'étudier la sécrétion de prolactine chez l'homme stérile et l'influence d'un traitement par la bromoergocryptine.

Douze hommes témoins et quatre-vingt-dix hommes stériles sont soumis à un bilan complet : spermogrammes, dosages radioimmunologiques de $\mathrm{FSH}$, LH prolactine et testostérone plasmatiques; dosage par chromatographie en phase gazeuse des androgènes urinaires ; tests de stimulation par le LHRH et le TRH. 18 patients stériles présentant une sécrétion élevée de prolactine sont traités pendant 1 mois par la bromoergocryptine $(5 \mathrm{mg}$ par jour) et subissent un nouveau bilan identique.

1. Les spermogrammes ef le test au LHRH permettent d'individualiser cinq groupes :

(1) témoins ; (2) oligospermiques eugonadotropes ; (3) oligospermiques hypogonadotropes; (4) oligospermiques hypergonadotropes : fortes réponses en $\mathrm{LH}$ et parfois $\mathrm{FSH}$, 
après LHRH ; (5) azoospermiques ou oligospermiques sévères avec blocage plus ou moins précoce de la spermatogenèse.

2. L'étude de la sécrétion de prolactine et de ses corrélations avec $\mathrm{FSH}, \mathrm{LH}$, testostérone et androgènes urinaires montre que :

- environ 40 p. 100 des hommes stériles ont une sécrétion de prolactine supérieure à la normale (avant ou après TRH) ;

- la prolactine, FSH et LH évoluent le plus souvent dans le même sens ;

- la prolactine est corrélée aux androgènes sanguins et urinaires dans la plupart des groupes. Cette corrélation devient négative dans les cas de blocage précoce de la spermatogenèse.

3. Le traitement par la bromoergocryptine pendant 1 mois a pour conséquences :

- une diminution de la prolactinémie et de la libération de prolactine au cours d'une stimulation par le TRH ;

- en moyenne une augmentation de $\mathrm{FSH}$ ef de $\mathrm{LH}$ et une diminution des androgènes. Ces modifications sont peu importantes et très variables d'un sujet à l'autre ;

- une augmentation significative du nombre de spermatozoïdes qui passe de $15.10^{6} / \mathrm{ml}$ à $31.10^{6} / \mathrm{ml}$.

\section{References}

AMBROSI B., TRAVAGLINI P., BECK-PECCOZ P., BARA R., ELLI R., PARACCHI A., FAGLIA G., 1976. Effect of sulpiride-induced hyperprolactinemia on serum testosterone response to HCG in normal men. J. clin. Endocr. Metab., 43, 700-703.

BARTKE A., 1971. Effects of prolactin on spermatogenesis in hypophysectomized mice. J. Endocr., 49, 311-316.

BARTKE A., LLOYD C. W., 1970. Influence of prolactin and pituitary isografts on spermatogenesis in dwarf mice and hypophysectomized rats. J. Endocr., 46, 321-329.

BARTKE A., CROFT B. T., DALTERIO S., 1975. Prolactin restores plasma testosterone levels and stimulates testicular growth in hamsters exposed to short day length. Endocrinology, 97, 1601-1610.

BEN-DAVID M., DANON A., SULMAN F. G., 1971. Evidence of antagonism between prolactin and gonadotrophin secretion : effect of methallibure on perphenazine-induced prolactin secretion in ovariectomized rats. J. Endocr., 51, 719-725.

BESSER G. M., PARKE L., EDWARDS C. R. W., FORSYTH I. A., MCNEILLY A. S., 1972. Galactorrhoea : successful treatment with reduction of plasma prolactin levels by brom-ergocryptine. Brit. med. J., (3), 669-672.

BESSER G. M., THORNER M. O., 1975. Prolactin and gonadal function. Path. Biol., 23, 779-782.

BOHNET H. G., DAHLEN H. G., SCHNEIDER H. P. G., 1974. Hyperprolactinemia and pulsatile LH fluctuation. Acta endocr., 75, suppl. 184, 109.

BOUCHER D., 1976. Les explorations hormonales de l'axe hypothalamo-hypophyso-ovarien. J. Med. Clermont, 4, 255-268.

BOUCHER D., HERMABESSIERE J., GAILLARD G., FRANCANNET M., 1976. Réponse en gonadostimulines sériques après stimulation par le LHRH chez l'homme. J. Physiol. Paris, 72, 36A.

BOUCHER D., HERMABESSIERE J., GRIZARD G., DOLY M., BRUHAT M., 1977. Explorations dynamiques LHRH + TRH de l'homme stérile. Rev. fran.. Gynéc. (sous presse).

BOWERS C. Y., FRIESEN H. G., FOLKERS K., 1973. Further evidence that TRH is also a physiological regulator of PRL secretion in man. Biochem. Biophys. Res. Commun., 51, 512-521.

BOYAR R. M., KAPEN S., FINKELSTEIN J. W., PERLOW M., SASSIN J. F., FUKUSHIMA D. $K$ WEITZMAN E. D., HELLMAN L., 1974. Hypothalamic-pituitary function in diverse hyperprolactinemic states. J. clin. Invest., 53, 1588-1598. 
DAVID G., BISSON J. P., CZYGLIK F., JOUANNET P., GERNIGON C., 1975. Anomalies morphologiques du spermatozoīde humain. 1) Propositions pour un système de classification. J. Gyn. Obst. Biol. Repr., 4, Suppl. 1, 17-36.

DEL POZO E., BRUN DEL RE R., VARGA L., FRIESEN H., 1972. The inhibition of prolactin secretion in man by CB 154 (2-Br- $\alpha$-ergocryptine). J. clin. Endocr. Metab., 35, 768-771.

DEL POZO E., VARGA H., WYSS H., TOLIS G., FRIESEN H., WENNER R., VETTER L., UETTWILER A., 1974. Clinical and hormonal response to bromocriptin (CB-154) in the galactorrhea syndromes. J. clin. Endocr. Metab., 39, 18-26.

DELVOYE P., TAUBERT H. D., JURGENSEN O., L'HERMITE M., DELOGNE J., ROBYN C., 1974. Influence of circulating prolactin increased by a psychotropic drug on gonadotrophin and progesterone secretion. Acto Endocr. $(K B H), 75$, suppl. 184, 110.

FANG V. S., REFETOFF S., ROSENFIELD R. L., 1974. Hypogonadism induced by a transplantable, prolactin-producing tumor in males rats : hormonal and morphological studies. Endocrinology, 95, 991-998.

FARNSWORTH W. E., 1972. In BOYNS A. R., GRIFFITHS K. Prolactin and carcinogenesis. Alpha omega, Alpha Pub., Cardiff, 217.

FOSSATI P., STRAUCH G., TOURNIAIRE J., 1976. Etude de l'activité de la bromocriptine dans les états d'hyperprolactinémie. Résultats d'un essai coopératif chez 135 patients. Nouv. Presse méd., 5, 1687-1691.

FRANCHIMONT P., VALCKE J. C., SCHELLENS., DEMOULIN A., LEGROS J. J., 1973. Action du LHRH sur les taux des gonadotrophines dans les différentes affections endocriniennes. Ann. Endocr., 34, 491-501.

FRANCHIMONT P., CHARI S., SCHELLEN, DEMOULIN A., 1975. Relationship between gonadotrophins, spermatogenesis and seminal plasma. J. Sieroid Biochem., 6, 1037-1042.

FRANCHIMONT P., REUTER A., VRINDTS-GEVAERT Y., VAN CAUWENBERGE J. R., DOURCY C., REMACLE P., LEGROS J. J., COLIN C., GASPARD U., 1976. Dosage de la prolactine dans les conditions normales et pathologiques. Impr. Bietlot Frères, 6220 Fleurus/1020 Bruxelles. Pp. 54.

GUYDA H., HWANG P., FRIESEN H., 1971. Immunologic evidence for monkey and human prolactin (MPr and Hpr). J. clin. Endocr. Metab., 32, 120-123.

HAFIEZ A., BARTKE A., LLOYD C. W., 1972. The role of prolactin in the regulation of testis function : the synergistic effects of prolactin and luteinizing hormone on the incorporation of $1{ }^{14} \mathrm{C}$ acetate into testosterone and cholesterol by testes from hypophysectomized rats in vitro. J. Endocr., 53, 223-230.

HAFIEZ A. A., LLOYD C. W., BARTKE A., 1972. The role of prolactin in the regulation of testis function : the effects of prolactin and luteinizing hormone on the plasma levels of testosterone and androstenedione in hypophysectomized rats. J. Endocr., 52, 327-332.

HELLER C. G., CLERMONT Y., 1963. Spermatogenesis in man : an estimate of its duration. Science, 140, 184-186.

HELLER C. G., CLERMONT Y., 1964. Kinetics of the germinal epithelium in man. Rec. Progr., Horm. Res., 20, 545-575.

HELLER C. G., TESHIMA F., ROWLEY M. J., 1969. Duration of transport of spermatozoa through the ductular system. Schering Symposium, Advanc. Biosci., 4, 121-131.

HWANG P., GUYDA H., FRIESEN H., 1971. A radio-immunoassay for human prolactin. Proc. nat. Acad. Sci., Wash., 68, 1902-1906.

JACOBS L. S., SNYDER P. J., WILBER J. F., UTIGER R. D., DAUGHADAY W. H., 1971. increased serum prolactin after administration of synthetic thyrotropin releasing hormone (TRH) in man. J. clin. Endocr. Metab., 33, 996-998.

JOHANSSON R., 1975. RNA, protein and DNA synthesis stimulated by testosterone, insulin and prolactin in the rat ventral prostate cultured in chemically defined medium. Acta Endocr., 80, 761-774.

JOHANSSON R., 1976. Effect of prolactin, growth hormone and insulin on the uptake and binding of dihydrotestosterone to the cultured rat ventral prostate. Acto Endocr., 81, 854-864.

KEDERLHUÉ B., CATIN S., KORDON C., JUTISZ M., 1976. Delayed effects of in vivo LHRH immunoneutralization on gonadotropins and prolactin secretion in the female rat. Endocrinology, 98, 1539-1549. 
KLEDZIK G. S., MARSHALL S., CAMPBELL G. A., GELATO M., MEITES J., 1976. Effects of castration, testosterone, estradiol, and prolactin on specific prolactin-binding activity in ventral prostate of male rats. Endocrinology, 98, 373-379.

LEWIS U. J., SINGH R. N. P., SINHA Y. N., VAN DER LAAN W. P., 1971. Electrophoretic evidence for human prolactin. J. clin. Endocr. Metab., 33, 153-156.

L'HERMITE M., DEGUELDRE M., CAUFRIEZ A., DELVOYE P., ROBYN C., 1975. Sécrétion de prolactine : intérêt des investigations dynamiques. Pathol. biol., 23, 769-778.

MAGRINI G., EBINER J. R., BURCKHARD P., FELBER J. P., 1976. Study on the relationship between plasma prolactin levels and androgen metabolism in man. J. clin. Endocr. Metab., 43, 944-947.

MORTIMER C. H., BESSER G. M., MCNEILLY A. S., MARSHALL J. C., HARSOULIS P., TUNBRIDGE W. M. G., GOMEZ-PAN A., HALL R., 1973a. Luteinizing hormone and follicle stimulating hormone-releasing hormone test in patients with hypothalamic-pituitary-gonadal dysfunction. Brit. med. J., 4, 73-79.

MORTIMER C. H., BESSER G. M., NCNEILLY A. S., TUNBRIDGE W. M. G., GOMEZ-PAN A., HALL R., 1973b. Interaction between secretion of the gonadotrophins, prolactin, growth hormone, thyrotrophin and corticosteroids in man : the effects of $\mathrm{LH} / \mathrm{FSH}-\mathrm{RH}$ and hypoglycemia alone and in combination. Clin. Endocr., 2, 317-326.

NEGRO-VILAR A., KRULICH L., MCCANN S. M., 1973. Changes in serum prolactin and gonadotropins during sexual development of the male rat. Endocrinology, 93, 660-664.

NOEL G. L., SUH H. K., STONE J. G., FRANTZ A. G., 1972. Human prolactin and growth hormone release during surgery and other conditions of stress. J. clin. Endocr. Metab., 35, 840-851.

NOKIN J., VEKEMANS M., L'HERMITE M., ROBYN C., 1972. Circadian periodicity of serum prolactin concentration in man. Brit. med. J., (3), 561-562.

RUBIN R. T., GOUIN P. R., LUBIN A., POLAND R. E., PIRKE K. M., 1975. Nocturnal increase of plasma testosterone in men : relation to gonadotropins and prolactin. J. clin. Endocr. Metab., 40, 1027-1033.

RUBIN R. T., POLAND R. E., TOWER B. B., 1976. Prolactin-related testosterone secretion in normal adult men. J. clin. Endocr. Metab., 42, 112-116.

SEKI K., SEKI M., OKUMURA T., 1975. Effect of CB-154 (2-Br- $\alpha$-ergocryptine) on serum follicle stimulating hormone, luteinizing hormone and prolactin in women with the amenorrhoeagalactorrhoea syndrome. Acta endocr., 79, 25-33.

SEPPALA M., UNERUS H. A., HIRVONEN E., RANTA T., 1976. Bromocryptine increase plasma cestradiol 17- $\beta$ concentration in amenorrhea patients with normal serum prolactin. $\mathrm{J}$. clin. endocr. Metab., 43, 474-477.

SETCHELL B. P., 1974. Secretions of the testis and epididymis. J. Reprod. Fert., 37, 165-177.

SNEDECOR C. W., COCHRAN W. G., 1967. Statistical methods. Ames, lowa, lowa State University Press.

THORNER M. O., MCNEILLY A. S., HAGAN C., BESSER G. M., 1974. Long term treatment of galactorrhoea and hypogonadism with bromocriptine. Brit. med. J., (2), 419-422.

WOODS M. C., SIMPSON M. E., 1961. Pituitary control of the testis of the hypophysectomized rat. J. Endocr., 69, 91-125. 